\title{
Trachyteuthis covacevichi n. sp., a Late Jurassic Palaeopacific coleoid cephalopod
}

\author{
Dirk Fuchs ${ }^{*}, 1$ and Hans-Peter Schultze ${ }^{2}$ \\ ${ }^{1}$ Institut für Paläontologie, Freie Universität Berlin, Malteserstraße 74-100, 12249 Berlin, Germany. E-mail: drig@zedat.fu-berlin.de \\ ${ }^{2}$ Natural History Museum /Biodiversity Research Center, and Dept. of Ecology \& Evolutionary Biology, The University of Kansas, Lawrence, \\ Kansas 66045, U.S.A. E-mail: hp1937@ku.edu
}

\begin{abstract}
Received 12 February 2007

Accepted 10 September 2007

Published 15 February 2008

A new early Oxfordian coleoid cephalopod, Trachyteuthis covacevichi n. sp., is described from northern Chile. It represents the first Late Jurassic Palaeopacific vampyropod and thus considerably extends the palaeogeographic distribution of trachyteuthids. In general, Tr. covacevichi n. sp. possesses a gladius typical for the genus, but wider

\section{Key Words}

Coleoid cephalopods

taxonomy

systematics than in other species. Similarities between Tr. covacevichi n. sp., Tr. palmeri from the Oxfordian of Cuba and $T r$. sp. from the Kimmeridgian of Europe confirm a Caribbean Seaway between the Tethys and the Palaeopacific during Late Jurassic times. Morphologically, the wide gladius of Tr. covacevichi $\mathrm{n}$. sp. supports a close phylogenetic relationship between Teudopsis and Trachyteuthis.
\end{abstract}

palaeobiogeography

phylogeny

Jurassic

Chile

\section{Introduction}

In general, the fossil record of coleoid cephalopods is poor. This is chiefly due to their reduced internal shell. In the scientific history of fossil coleoids, comprehensive studies concerning morphology, evolution, diversity and distribution appeared only sporadically over a long time period. Only two major monographs on fossil coleoids published by Naef (1922) and Jeletzky (1966) exist. However, increased interests in the last twenty years of coleoid research provided a series of additional information that significantly influenced our ideas about the palaeobiology of the Coleoidea (Bandel \& Leich 1986; Doguzhaeva 1996, 2000; Doguzhaeva et al. 1999; Haas 2002; Donovan et al. 2003; Fuchs et al. 2003; Klug et al. 2005; Fuchs 2006a, b, c).

The morphological understanding of some coleoid groups such as the trachyteuthids has been particularly improved (Doyle 1991; Doguzhaeva \& Mutvei 2003; Donovan et al. 2003; Klug et al. 2005; Fuchs 2006a). It has been shown that this group had an almost cosmopolitan distribution and a comparatively great longevity from the Middle Jurassic to the latest Cretaceous (Fuchs 2006a, b). Particularly during Jurassic times, they have been a diverse and abundant group at least in the Tethys realm. Numerous specimens have been identified as trachyteuthids from the Callovian of England (Martill \& Hudson 1994), the Oxfordian of Cuba (Schevill 1950), the Kimmeridgian of England (Hewitt \& Wignall 1988) and Germany (Klug et al. 2005), and from the Tithonian of Germany (Fuchs 2006a and references therein), Russia (Hecker \& Hecker 1955) and Antarctica (Doyle 1991). In contrast, only a handful of records have been available from the Palaeopacific; all from the Oxfordian of Chile (Schultze 1989; Fuchs 2006a; Rubilar \& Pérez d'A. 2006).

These specimens from the Jurassic of Chile were collected during an expedition sponsored by the National Geographic Society and conducted by members of the Museum of Natural History, University of Kansas, Lawrence, Kansas, USA (G. Arratia, H.-P. Schultze, K. Shaw, J. Chorn) with V. Covacevich (Servicio Nacional de Geología y Minería, Santiago, Chile) as guest in 1994. Since this material has never been considered

* Corresponding author 
previously in a taxonomic context, it is the aim of the present paper to describe the Chilean material.

\section{Geological setting}

The fossil localities in ravines north of Quebrada del Profeta, Sierra Varas, Cordillera de Domeyko (Fig. 1) have been discovered by Guillermo Chong, Universidad del Norte, Antofagasta, Chile, in the 1960s and visited by the junior author in 1978 and 1994 (for more details see Schultze 1989, figs 1, 2 and Arratia \& Schultze 1999, figs 1, 14). The Jurassic is folded tectonically so that the fossil horizons are repeated in the ravines from east to west (Schultze 1989, fig. 2). Schultze (1989, fig. 3) gave a section through the sequence showing the occurrence of ten horizons with concretions in black sandy shales. The coleoid-bearing concretions were collected from the main fossil bearing horizon 10. These concretions are calcareous (Schultze 1989, fig. 18) and occur in calcite-containing sandy shales. In contrast, the three-dimensionally preserved fossils within the concretions are phosphatic. Soft tissues are preserved in calcium phosphate (fluorapatite) in these concretions (Schultze 1989, fig. 20). Schultze (1989) argued that the phosphatisation of the muscle tissue of fishes must have occurred before they were imbedded, because muscle pieces are distributed irregularly like bones in concretions with disarticulated fishes (Schultze 1989, pl. 4, fig. 3). Ammonites are preserved with their siphuncles. Soft tissue occurs also in association with coleoid cephalopods (see below). In contrast, calcitic or aragonitic bivalve shells are poorly preserved.

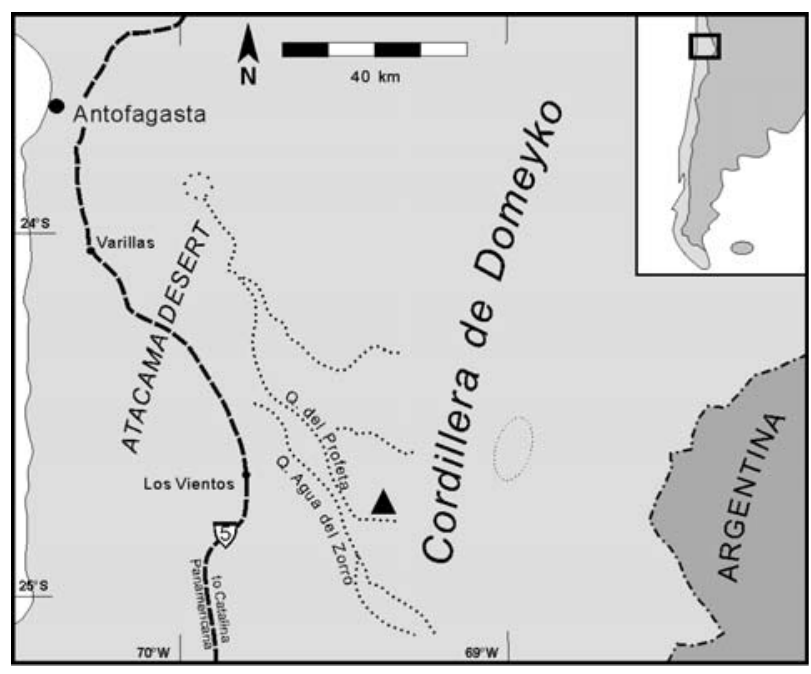

Figure 1. Map of South America with detail of the Cordillera de Domeyko in Chile. The geographic position of the exposures north of Quebrada del Profeta is marked by a black triangle.

Most of the fishes are complete and must have been imbedded relatively quickly. Disarticulated fishes and especially all the disarticulated crustacean remains indicate a longer interval on the sediment, which passed prior to the formation of the concretions. The parts of disarticulated specimens are not current-aligned and thus, currents did probably not affect the sediment surface. The ammonites are free of epizoans, and the bivalves are not attached to any ammonites; thus, there is no direct indication that they were drifted into this depositional environment.

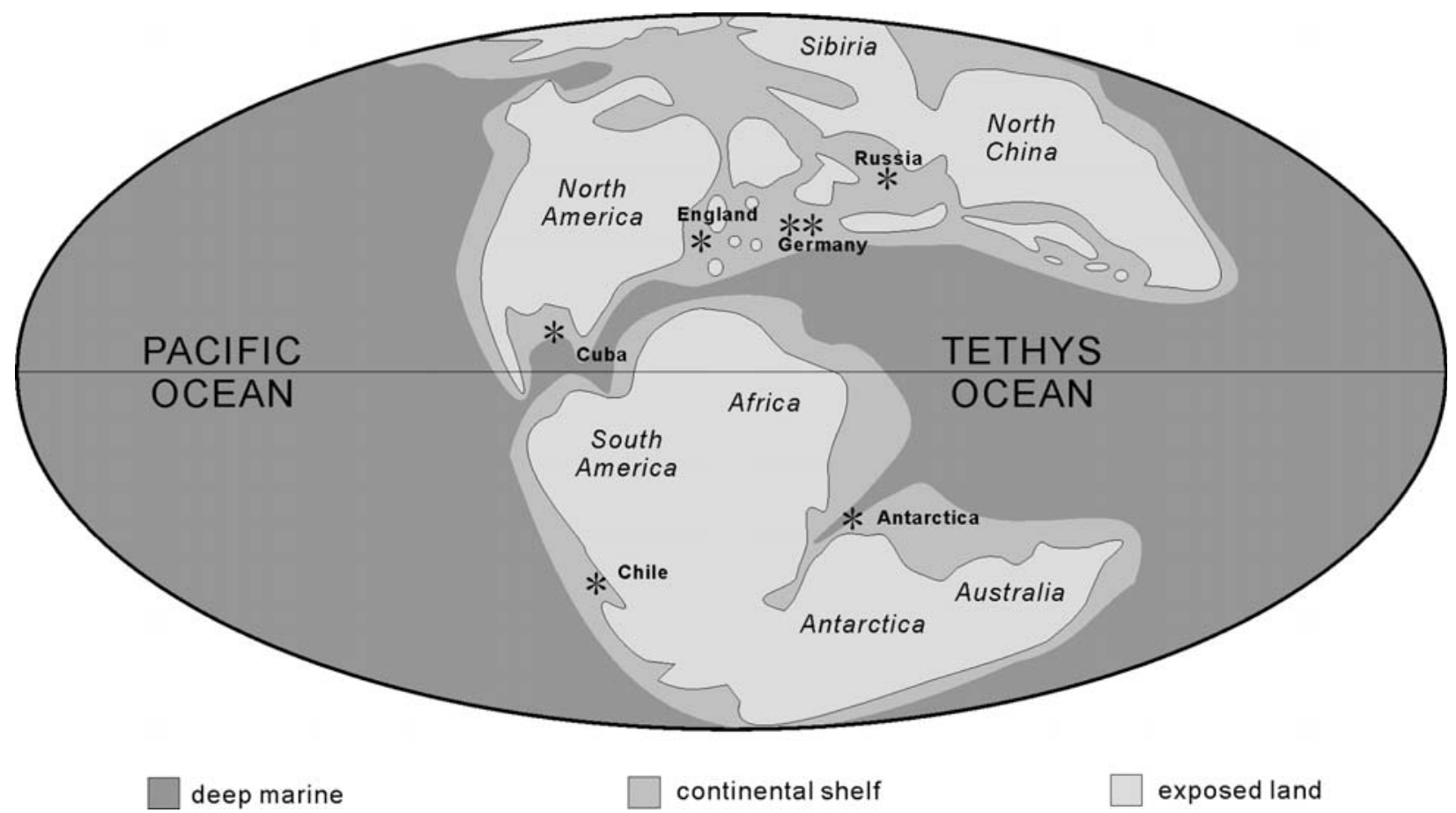

Figure 2. Scheme of the palaeogeographic situation during Late Jurassic times (modified after Smith et al. 1994). Records of Trachyteuthis are marked by asterisks. 
Palaeogeographic maps for the Oxfordian place the Chilean locality close to the western margin of Gondwana (Fig. 2). The fishes indicate a near-coast environment (pycnodontiform and semionotid) with some open-sea elements (pachycormid fishes, ichthyosaurs). The clusters of oysters and the occurrence of decapod crustaceans point to shallow water depths, possibly below $30 \mathrm{~m}$ and certainly above $100 \mathrm{~m}$.

\section{Associated fauna}

Common fossils at the locality are bony fishes (actinopterygians; Arratia \& Schultze 1999): the pycnodontiform Gyrodus sp. (Kriwet 2000), the semionotid Lepidotes sp. (Arratia, 1987; Arratia \& Cione 1996), Hypsocormus-like pachycormids (Arratia 1987), the possible stem teleosts Atacamichthys (figured as amiiform in Arratia 1987) and Teleost sp. 1 (Arratia \& Schultze 1999), and teleosts, Varasichthyidae (Varasichthys, Bobbichthys, Domeykos, Protoclupea; Arratia \& Cione 1996), Chongichthyidae (Chongichthys; Arratia \& Cione 1996), as well as Teleostei incertae sedis (?Pholidophorus domeykanus; Arratia \& Cione 1996). Few reptile bones have been discovered, these are common in corresponding horizons in Quebrada de San Pedro near Caracoles (crocodiles and ichthyosaurs) at the northern end of the Cordillera de Domeyko.

A single specimen of the decapod crustacean Chilenophoberus atacamensis Chong \& Förster, 1976 was described as a unique occurrence (Chong \& Förster 1976). In reality, Chilenophoberus is the most common fossil at these localities, not as complete specimens (Arratia 1987, pl. 3, fig. 1), but in form of disarticulated parts of carapaces, abdomens, telsons and uropods (Schultze 1989, pl. 1, fig. 4), which were mistakenly interpreted as shrivelled fish scales. The ammonites (Perisphinctes sp., Euaspidoceras sp. and other; Schultze 1989, pl. 1, fig. 5) have not yet been described properly. Bivalves (oysters and "Posidonia"; Schultze 1989 , pl. 1, fig. 3) are poorly preserved. Coleoid cephalopods were discovered in 1978 (Schultze 1989, pl. 1, fig. 2) and 1994 (described here). Only one single lingulid brachiopod has been found. In addition, algae occur (Schultze 1989, pl. 1, fig. 1).

Like today, Northern Chile was positioned at the western margin of the South American continent during Jurassic times (Fig. 2). An area cladogram and the interrelationships of varasichthyids (Arratia 1994) indicate a connection between the Palaeopacific coast of Chile and Cuba through the open straight between North and South America in the early Late Jurassic. The varasichthyids migrated through the western Tethys to Europe in the Late Jurassic (Arratia 1994). The pycnodontid genus Gyrodus shows the same distribution as the varasichthyids. The genus Gyrodus occurs along the eastern maritime coast of South America and in westernmost parts of the Tethys (Cuba), with a later expansion to Europe (Kriwet 2000).

\section{Systematic Palaeontology}

Subclass Coleoidea Bather, 1888

Superorder Vampyropoda Boletzky, 1992

Order Octobrachia Fioroni, 1982

Suborder Teudopseina Starobogatov, 1983

Families included. Trachyteuthididae Naef, 1921, Teudopseidae Regteren Altena, 1949, Palaeololiginidae Naef, 1921, and Muensterellidae Roger, 1952.

Family Trachyteuthididae Naef, 1921

Type genus. Trachyteuthis Meyer, 1846

Genera included. Trachyteuthis Meyer, 1846, Glyphiteuthis Reuss, 1854, and Actinosepia Whiteaves, 1897.

Stratigraphic and geographic range. Middle Jurassic (Callovian) to Late Cretaceous (Maastrichtian); Europe, Central Russia, Lebanon, Cuba, Chile, Antarctica, Australia, and North America.

Remarks. Systematically, Trachyteuthis was placed in various coleoid groups. Rüppell (1829), who described the type species Trachyteuthis hastiformis, and several other workers from that time, regarded the remains as a sepiid cuttlebone owing to the presence of characteristic dorsal granulations. Owen (1855) considered Trachyteuthis to be intermediate between sepiids and teuthids. Naef (1922) and Jeletzky (1966) put Trachyteuthis along with the socalled "fossil teuthids", whereas Donovan (1977) assigned it again to the sepiids. Bandel \& Leich (1986) introduced an alternative idea. Since Trachyteuthis and other "fossil teuthids" such as Plesioteuthis and Leptotheuthis never show more than eight arms, these authors regarded them as early members of the vampyropod order Vampyromorpha Robson, 1929, the sister taxon of the Octobrachia (Octopoda + Cirroctopoda). Recent discoveries of well-preserved Trachyteuthis with two pairs of fins supported vampyropod relationships (Donovan et al. 2003). Furthermore, Haas (2002) and Bizikov (2004) claimed that gladius vestiges of Recent octopods and cirroctopods evolved through the gradual reduction of teudopseid-like gladii, which means that Teudopseina represent a stemgroup of the Octobrachia.

The presence of two pairs of fins, eight arms, cirri and arm web as well as the absence of a chambered phragmocone led us to place Trachyteuthis within the Vampyropoda and the argumentation of Haas (2002) and Bizikov (2004) convinced us to assume affiliations to the Octobrachia rather than to the Vampyromorpha.

The Late Cretaceous genus Libanoteuthis Kretzoi, 1942 is regarded to be a junior synonym of Glyphiteuthis Reuss, 1854 (Fuchs 2006b).

\section{Trachyteuthis Meyer, 1846}

Type species. Trachyteuthis ensiformis Meyer, 1846 (= junior subjective synonym of Sepia hastiformis Rüppell, 1829), Tithonian (Late Jurassic), Solnhofen region, southern Germany, subsequently designated by Doyle et al. (1994, p. 11). 
Diagnosis. Gladius with a hyperbolar zone length/gladius length ratio of $0.40-0.45$. Anterior gladius end more or less arcuated.

Species included. Tr. hastiformis (Rüppell, 1829), Tr. latipinnis (Owen, 1855), Tr. zhuravlevi Hecker \& Hecker, 1955, Tr. palmeri (Schevill, 1950), Tr. nusplingensis Fuchs et al. (2007), Tr. teudopsiformis Fuchs et al. (2007), Tr. willisi Wade, 1993, Tr. covacevichi $\mathrm{n}$. sp.

Stratigraphic and geographic range. Middle Jurassic (Callovian) to Late Cretaceous (Cenomanian); Europe, Central Russia, Cuba, Chile, Antarctica, Australia and Lebanon.

Remarks. Meyer (1846) introduced the genus Trachyteuthis without detailed descriptions or illustrations.
Crick (1896) therefore proposed that Trachyteuthis Meyer, 1846 is a junior subjective synonym of Coccoteuthis Owen, 1855, because a full description of Trachyteuthis by Meyer (1855) was published slightly after the erection of Coccoteuthis by Owen (1855). However, the bibliographic reference to plate 9, fig. 3 in Münster (1846) is valid after the ICZN (Art. 12). Most recent workers therefore considered Coccoteuthis to be a junior subjective synonym of Trachyteuthis (Engeser 1988; Doyle 1991; Doyle et al. 1994, Donovan 1995; Riegraf et al. 1998). Voltzia Schevill, 1950 is a junior subjective synonym, too.

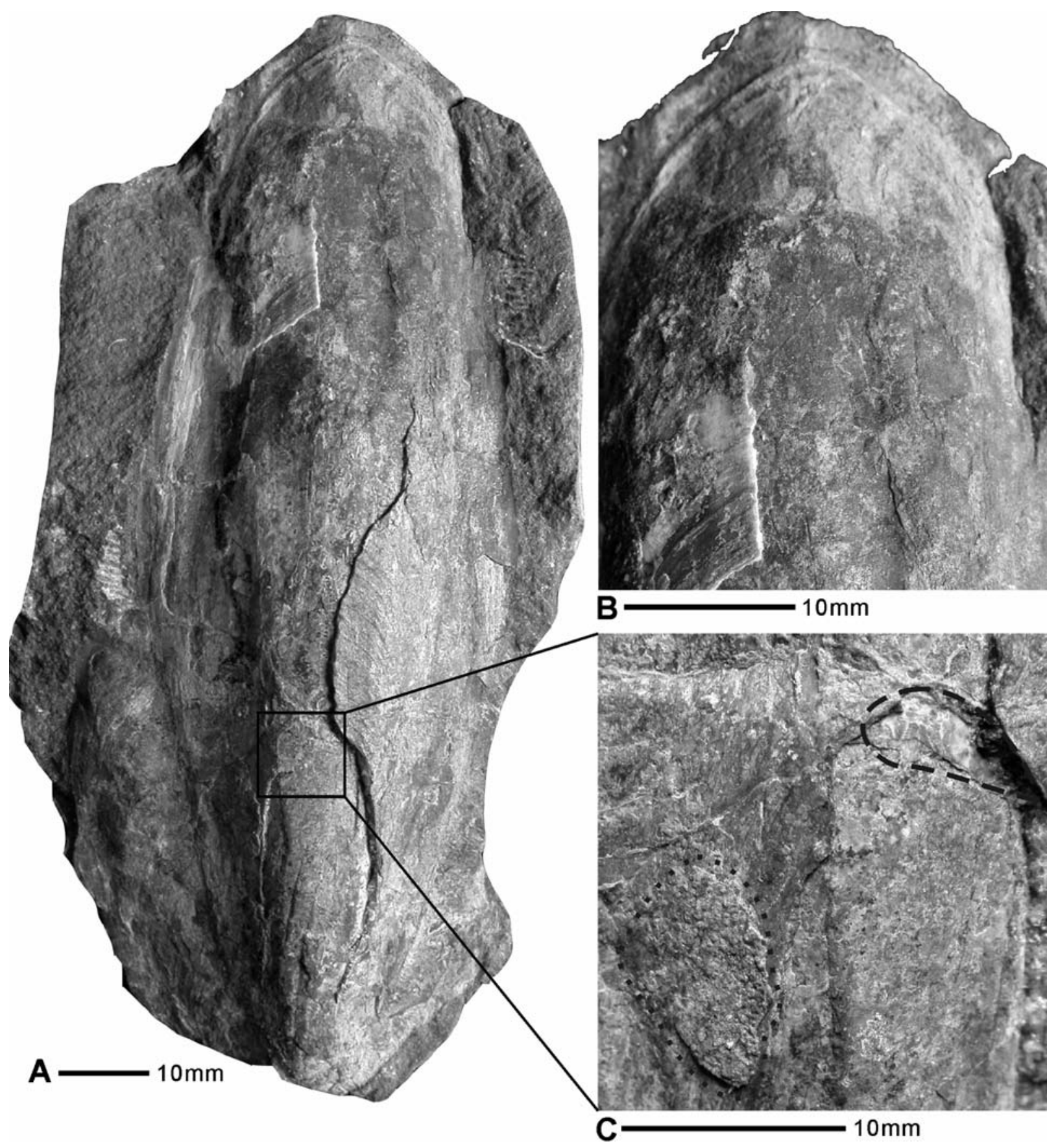

Figure 3. Trachyteuthis covacevichi $\mathrm{n}$. sp. from Cordillera de Domeyko, Chile. A. Specimen SGO.PI.6437a (part), gladius in dorsal view; B. Detail of A, showing the anterior third of the gladius; C. Detail of $\mathbf{A}$, showing three gladius layers; dotted line dorsal (outer) granulated layer; dashed line - ventral (inner) layer. 


\section{Trachyteuthis covacevichi $\mathbf{n} . \mathbf{s p}$.}

Figures 3-5

1989 Plesioteuthis sp. Schultze: pl. 1, fig. 2.

2006 Trachyteuthis sp. Fuchs a: pl. 14, fig. F.

2006 Trachyteuthis sp. Rubilar \& Pérez d'A.: fig. 2A-B, C.
Derivation of name. In honour of the late Vladimir Covacevich, geologist and invertebrate palaeontologist of the Servicio Nacional de Geologia y Minera de Chile, who was member of the field party in 1994.

Holotype. Specimen SGO.PI.6437a + b (Figs 3-4), deposited in the Museum Nacional de Historia Natural, Santiago (Chile).
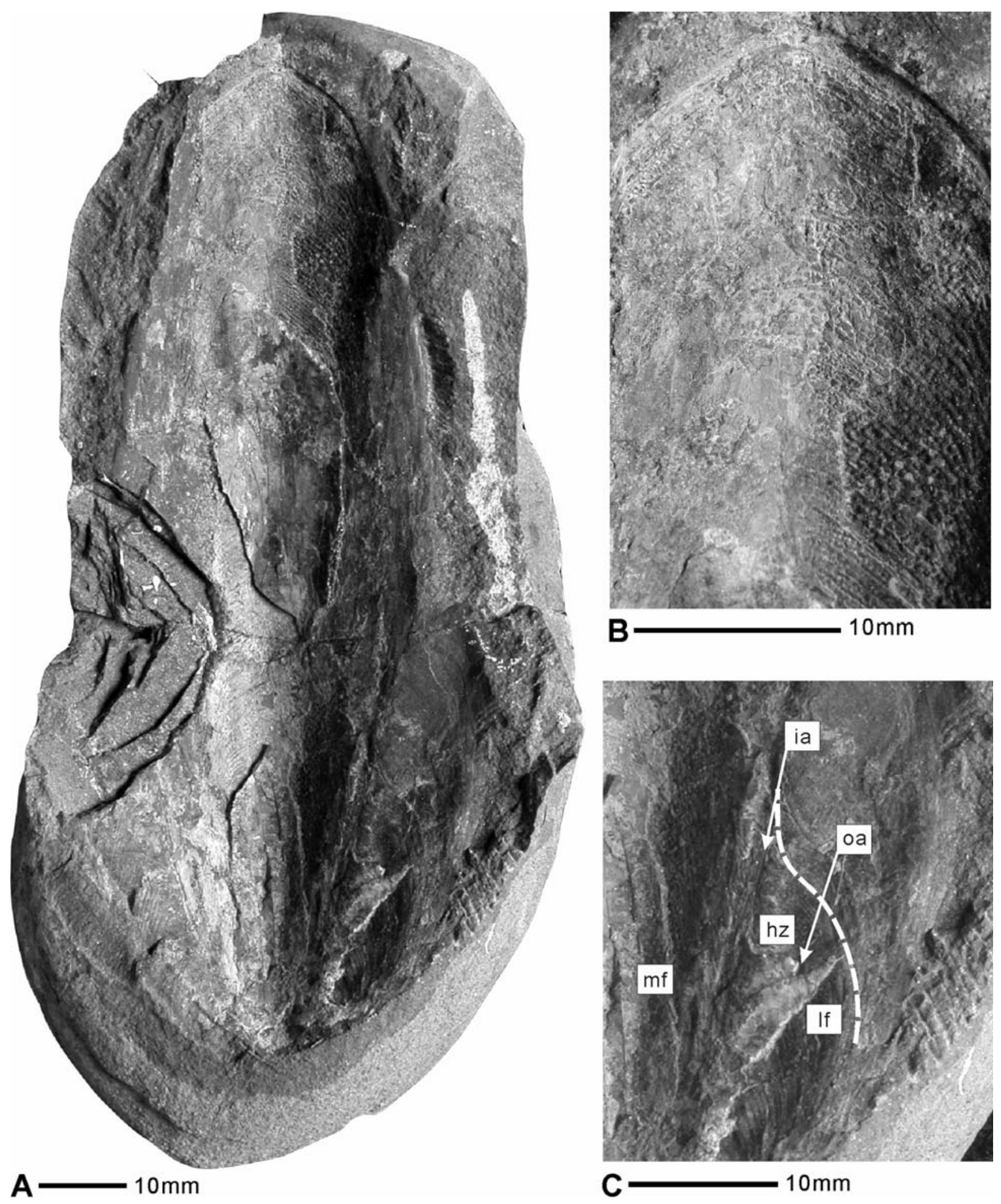

Figure 4. Trachyteuthis covacevichi n. sp. from Cordillera de Domeyko, Chile. A. Specimen SGO.PI.6437b (counterpart), gladius in ventral view; B. Detail of A, showing dorsal imprints of the granulae; $\mathbf{C}$. Detail of $\mathbf{A}$, showing the course of growth increments; ia - inner asymptote, $\mathbf{h z}$ - hyperbolar zone, lf - lateral field, $\mathbf{m f}$ - median field, oa - outer asymptote, dashed line - growth increment. 
Type locality. Tributaries north of Quebrada del Profeta, Sierra de Varas, Cordillera de Domeyko, northern Chile.

Type horizon. Uncertain (probably cordatum zone); early Oxfordian, Late Jurassic

Additional material. One specimen, SGO.PI.6438 (Fig. 5).

Diagnosis. Gladius shape comparatively wide and compact, anterior end weakly pointed, granulated area diverge at an angle of 15 degrees.

Description. The material includes three-dimensionally uncompressed gladii. The holotype consists of part (SGO.PI.6437a, Fig. 3) and counterpart (SGO.PI.6437b, Fig. 4). The gladius of the holotype is in an excellent condition (only outermost margins of the lateral fields are partly missing). It was embedded on the venter. Specimen SGO.PI.6438 preserves a juvenile gladius of

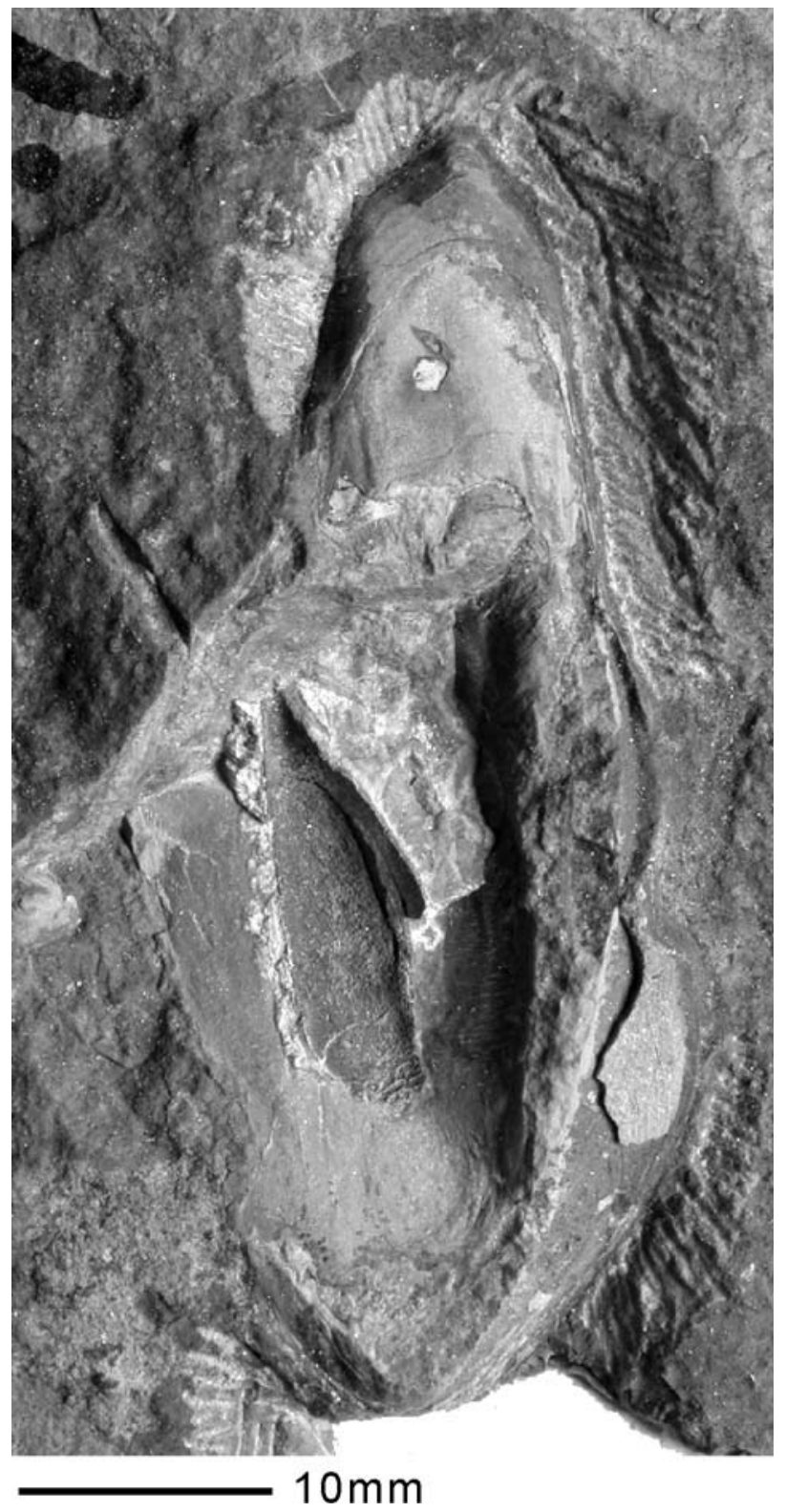

Figure 5. Trachyteuthis covacevichi n. sp. from Cordillera de Domeyko, Chile. Specimen SGO.PI.6438, gladius seen in dorsal view.
$52 \mathrm{~mm}$ length (Fig. 5). It is in very bad condition showing no relevant characters.

The gladius of the holotype has a total length of $125 \mathrm{~mm}$. Median field, hyperbolar zones and lateral fields are clearly distinguishable owing to growth lines visible on both part and counterpart (Fig. 4A, C). Hyperbolar zone is $55 \mathrm{~mm}$, the lateral field $38 \mathrm{~mm}$ in length. Hyperbolar zone is gently curved. Gladius width is $38 \mathrm{~mm}$ at half of the gladius length (approximately the anterior end of the hyperbolar zone) and $50 \mathrm{~mm}$ at the anterior end of the lateral field. Maximum gladius width is $56 \mathrm{~mm}$ (morphometric indices are given in Table 1). Inner asymptotes that delimit the hyperbolar zones from the median field, are well marked by ridges; they diverge with an angle of 40 degrees. Outer asymptotes are indistinct.

Imprints of the dorsal gladius surface are visible on specimen SGO.PI.6437b. Especially the anterior third of this specimen shows distinct imprints of granulae typical for Trachyteuthis (Fig. 4B). Granulae are arranged in accordance with growth increments as seen in SGO.PI.6437a (Fig. 3B). The arcuated growth lines reflect the weakly pointed anterior gladius end. The granulated area forms a comparatively broad band diverging from posterior to anterior at an angle of 15 degrees. A median keel or line is absent.

The sturdy gladius consists of three main layers. The ventral layer generally adheres to the part (Fig. 3A-C); the dorsal granulated layer to the counterpart (Fig. 4A, B). Small pieces of the granulated dorsal layer can be also seen on the part (Fig. 3B, C). The intermediate layer, which is the thickest layer, is exposed on both parts. Its inner surface is almost smooth. Growth lines are very weak, but distinct longitudinal ridges are crossing the growth lines (Fig. 4A). By contrast, the outer surface of the intermediate layer displays distinct growth increments (Fig. 3B).

Though we did not analyse the mineralogy, the gladius is most probably preserved in francolite. A primary aragonitic gladius composition appears unlikely, because aragonitic shells have been dissolved in Oxfordian deposits of the Cordillera de Domeyko. It is more probable that the original gladius composition was chitinous (Doguzhaeva et al. 2003; Fuchs 2006a).

One can easily recognize the natural inflection of the gladius because of its three-dimensionality. The median field shows a remarkable longitudinal as well as transversal convexity. This convexity is stronger in the posterior part than in the anterior. The flexion decreases at the transition from the hyperbolar zone to the lateral fields. The lateral fields follow the longitudinal inflection of the median field, but not the transversal direction.

Most of the soft tissue is dissolved except for mantle musculature that is preserved in a very few places, and imprints of the ink sac.

Stratigraphic and geographic range. Known only from the type locality. 
Table 1. Comparison of morphometric indices and some other gladius characters between Tr. hastiformis, Tr. nusplingensis, Tr. teudopsiformis and Tr. covacevichi $\mathrm{n}$. sp.

\begin{tabular}{|c|c|c|c|c|}
\hline Measurements & Tr. hastiformis & Tr. nusplingensis & Tr. teudopsiformis & Tr. covacevichi n. sp. \\
\hline hyperbolar zone length/gladius length HZL/GL & $0.39-0.4$ & 0.36 & $?$ & 0.44 \\
\hline lateral field length/gladius length LFL/GL & $0.34-0.35$ & 0.32 & ? & 0.4 \\
\hline $\begin{array}{l}\text { gladius width at the anterior end of the hyperbolar } \\
\text { zones/gladius width } \mathrm{GW} h \mathrm{hz} / \mathrm{GL}\end{array}$ & $0.27-0.28$ & 0.27 & $?$ & 0.3 \\
\hline $\begin{array}{l}\text { gladius width at anterior end of the lateral fields/gladius } \\
\text { width } \mathrm{GW}_{\mathrm{If}} / \mathrm{GL}\end{array}$ & $0.34-0.35$ & 0.34 & ? & 0.4 \\
\hline maximum gladius width/gladius length $\mathrm{GW}_{\max } / \mathrm{GL}$ & $0.35-0.37$ & 0.39 & $?$ & 0.45 \\
\hline $\begin{array}{l}\text { gladius width at the half gladius length/gladius } \\
\text { width } \mathrm{GW}_{1 / 2 \mathrm{~g}} / \mathrm{GL}\end{array}$ & $0.26-0.27$ & 0.27 & $?$ & 0.3 \\
\hline $\begin{array}{l}\text { maximum gladius width/hyperbolar zone length } \\
\mathrm{GW}_{\max } / \mathrm{HZL}\end{array}$ & $0.87-0.93$ & 1.05 & $?$ & 1.01 \\
\hline angle of diverging inner asymptotes $A_{i a}$ & $40^{\circ}$ & $40^{\circ}$ & $43^{\circ}$ & $40^{\circ}$ \\
\hline angle of diverging granulated area $A_{g a}$ & 1 & $12^{\circ}$ & restricted to keel & $15^{\circ}$ \\
\hline granulation & coarse, irregular & fine, regular & coarse, regular & fine, regular \\
\hline keel & absent & absent & present & absent \\
\hline spindel-shaped deformation on the median field & present & absent & absent & absent \\
\hline preservation & \pm flattened & \pm flattened & \pm flattened & 3-dimensional \\
\hline
\end{tabular}

Discussion. The specimens illustrated in Rubilar \& Pérez d'A. (2006, fig. 2A-B, D), have been collected at the same locality by the same field crew. We have not yet investigated these specimens in detail, but they are most probably identical with Tr. covacevichi n. sp. The Callovian gladius shown in Rubilar \& Pérez d'A. (2006, fig. 2C) bears a strongly pronounced median keel and apparently lacks the dorsal granulation. It might be identical with Teudopsis jeletzkyi from the Callovian of Argentina (Riccardi 2005).

In general, the gladius outline of Tr. covacevichi $\mathrm{n}$. sp. is very similar to that of Tr. hastiformis (Fig. 6A, E) and Tr. nusplingensis (Fig. 6B, F). However, gladii from the Solnhofen and Nusplingen Limestones are more or less flattened; gladius shape comparisons between flattened and three-dimensional gladii are therefore problematic. Lengths and particularly widths obtained from flattened gladii are highly depending on the rate of compaction since the gladii have been originally flexed. Width-length ratios $\left(\mathrm{GW}_{\max } / \mathrm{GL}, \mathrm{GW}_{1 / 2 \mathrm{~g}} / \mathrm{GL}\right.$ and $\mathrm{GW}_{\mathrm{hz}} / \mathrm{GL}$, see Table 1 for explanations) given for flattened specimens are therefore only approximate (tentatively too wide), whereas measurements obtained from three-dimensional gladii are more accurate. Nevertheless, the high widthlength ratios obtained from Tr. covacevichi $n$. sp. indicate a wider gladius than in Tr. hastiformis or Tr. nusplingensis (Fig. 6, Tab. 1). Also the ratios LFL/GL and HZL/GL are higher in $T r$. covacevichi, suggesting generally a more compact gladius shape. Apart from the outline, the gladius of $T r$. covacevichi n. sp. can be clearly distinguished from Tr. hastiformis by the lack of the spindleshaped deformation that is characteristic for the median field of Tr. hastiformis (Fuchs 2006a; Fuchs et al. 2007). The granulation of Tr. nusplingensis is very si- milar to Tr. covacevichi n. sp., but the granulated area of the former diverges at a smaller angle (Fig. 6, Tab. 1).

Tr. teudopsiformis from Solnhofen can be easily distinguished from $T r$. covacevichi $\mathrm{n}$. sp. by an extremely narrow granulated area that is restricted to a median keel.

The shape of the anterior gladius margin in Tr. covacevichi n. sp. shows close similarities to contemporary Tr. palmeri, but a precise comparison is difficult because lateral fields, hyperbolar zones as well as details about the granulation are still unknown in Tr. palmeri. It is likewise difficult to compare Tr. covacevichi n. sp. and Callovian Tr. sp. (Martill \& Hudson 1994), the oldest known trachyteuthid. However, it seems that Tr. sp. displays higher LFL/GL and HZL/GL-ratios than our specimens (own observation).

Determination of differences between Tr. covacevichi n. sp. and other species of Trachyteuthis, Tr. cf. hastiformis from Antarctica, Tr. zhuravlevi from Russia, Tr. sp. from Helgoland, Tr. willisi from Australia, and Tr. cf. hastiformis from Lebanon, are problematic, because they have been identified by very few fragmentary specimens that offer only parts of the granulated area or imprints of the dorsal gladius surface. Distinctive characters as listed in Table 1 are thus unknown from these specimens.

The general gladius shape of Tr. covacevichi $\mathrm{n}$. $\mathrm{sp}$. is very close to the Toarcian genus Teudopsis, but the former can be easily distinguished by the possession of dorsal granulation and the absence of a pronounced median keel. Tr. covacevichi n. sp. clearly differs from Late Cretaceous genera Glyphiteuthis and Actinosepia by having higher LFL/GL- and HZL/GL-ratios, a less pointed anterior margin and by a planar median field without keel. 

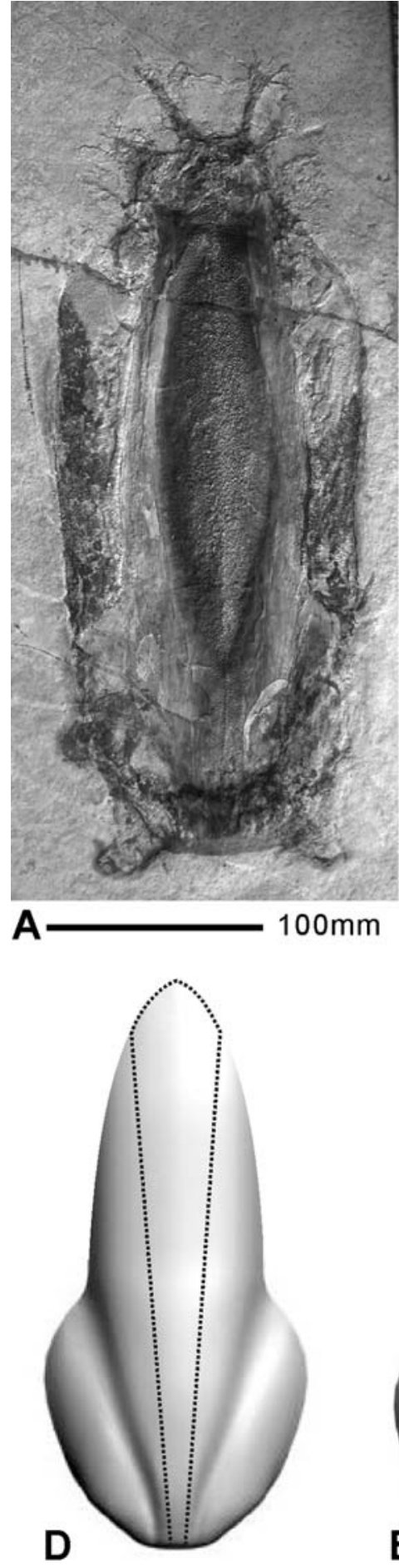

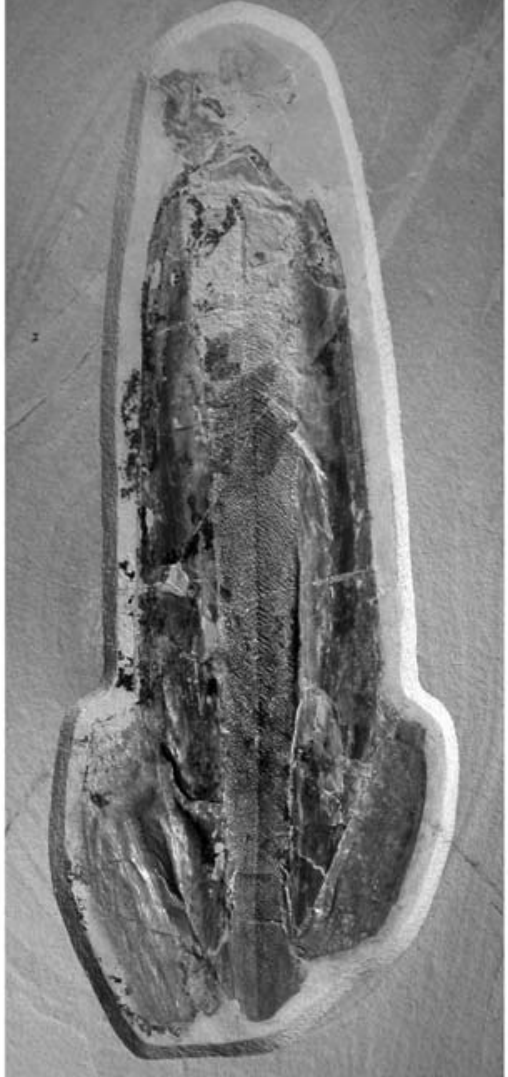

B

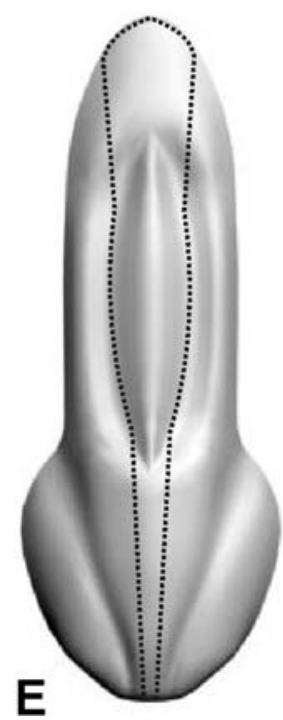

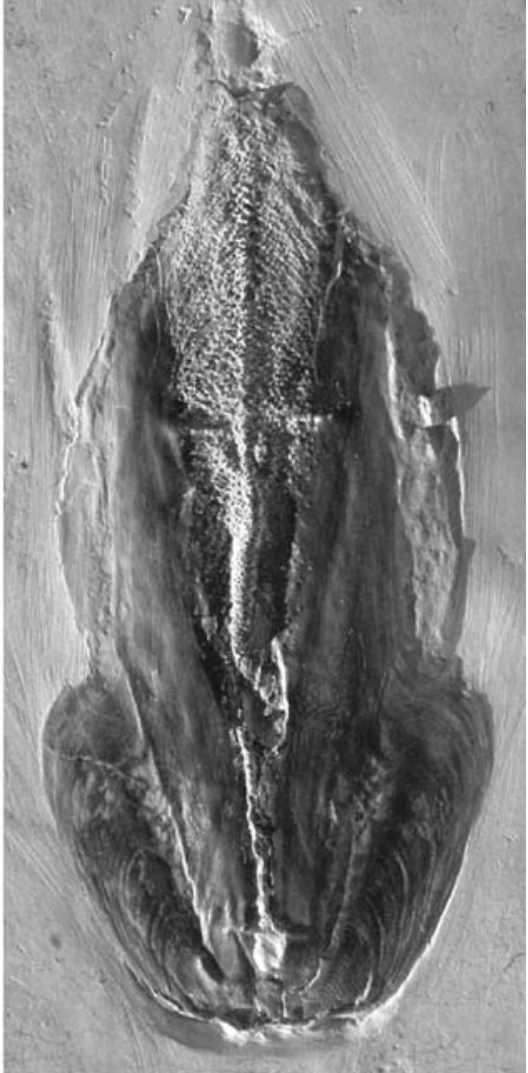

C

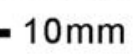

Figure 6. A. Trachyteuthis hastiformis (Rüppell, 1829) from Solnhofen (SOS 5762, Jura Museum Eichstätt), note the spindleshaped elevation on the median field; B. Trachyteuthis nusplingensis Fuchs et al. (2007) from Nusplingen (SMNS 63596, Staatliches Museum für Naturkunde Stuttgart); C. Trachyteuthis teudopsiformis Fuchs et al. (2007) from Solnhofen (G 1306061, Museum Berger, Eichstätt); D. 3D reconstruction of the gladius of Trachyteuthis covacevichi n. sp.; E. 3D reconstruction of Trachyteuthis hastiformis; F. 3D reconstruction of Trachyteuthis nusplingensis; G. 3D reconstruction of Trachyteuthis teudopsiformis; GL - gladius length; $\mathbf{G W}_{\mathbf{1} / \mathbf{2 g l}}$ - gladius width at the half gladius length; $\mathbf{G W}_{\mathbf{h z}}$ - gladius width at the anterior end of the hyperbolar zone; $\mathbf{G W}_{\text {If }}$ - gladius width at the anterior end of the lateral field; $\mathbf{G W}_{\mathbf{m a x}}$ - maximum gladius width; HZL - hyperbolar zone length; hz - hyperbolar zone; ia - inner asymptote; LFL - lateral field length; lf - lateral field; mf - median field; oa - outer asymptote. 


\section{Conclusions}

Most Jurassic vampyropods have been reported from the Tethyan realm (Fig. 7). To date, only three taxa have been recorded from outside the Tethys. Toarcian Teudopsis cadominensis and Paraplesioteuthis hastata are known from the Western Interior Basin of North America (Hall 1985; Hall \& Neuman 1989). Similarities with their western Tethys coevals indicate a marine connection between Tethys and Palaeopacific via the Arctic Sea (Hall 1985; Hall \& Neuman 1989). Teudopsis jeletzkyi from the Callovian of Argentina is the only record from the Southern Palaeopacific during the Toarcian. Hence, Tr. covacevichi n. sp. represents the second Jurassic and the first Late Jurassic vampyropod from the Palaeopacific. The record of Tr. covacevichi n. sp. indicates a wide palaeogeographic distribution of trachyteuthids during the Jurassic period, which supports earlier assumptions concerning a worldwide distribution of ancestral coleoids (Doyle 1991).

Phylogenetically, the compact gladius shape of Tr. covacevichi $\mathrm{n}$. sp. supports the idea that trachyteuthids developed from Teudopsis-like forms during the early Middle Jurassic (Fuchs 2006a; Fuchs et al. 2007). In the light of this, Tr. covacevichi n. sp. retained a comparatively wide and anteriorly pointed gladius (Fig. 7). Unfortunately, it is still uncertain if the stratigraphically oldest record of Trachyteuthis from the Callovian of England, exhibits a more primitive gladius shape.
As the rarity of coleoids in the fossil record is certainly a diagenetic artefact induced by their poor preservational potential, conclusions on their palaeobiogeography have to be drawn with reservation. However, the close similarity between Tr. palmeri from the Oxfordian of Cuba, Tr. covacevichi $n$. sp. from the Oxfordian of Chile, and Trachyteuthis from the European Kimmeridgian confirms a Caribbean seaway between the Tethys and the Palaeopacific starting with the Middle Jurassic. With respect to the results presented herein, further conclusions about the place of origin of trachyteuthids depend on the detailed gladius morphology of the English Callovian Trachyteuthis. As North American Teudopsis cadominensis, South American Teudopsis jeletzkyi and European Teudopsis subcostata are very similar, the origin of trachyteuthids might have occurred in the Palaeopacific or in the Tethys. If the poorly known gladius shape of the Callovian Trachyteuthis from England links Teudopsis and Trachyteuthis, a migration of trachyteuthids from the Tethys to the Palaeopacific in the early Middle Jurassic is conceivable. If $T r$. covacevichi $\mathrm{n}$. sp. is more primitive than the Callovian species, however, it is also conceivable that Trachyteuthis originated in the southern Palaeopacific and migrated to the Tethys. In the latter case, the distribution would correspond to that of the fishes of the Cordillera de Domeyko, Chile, and Vinales, Cuba (Arratia 1994; Kriwet 2000). The faunal association indicates a shallow coastal marine

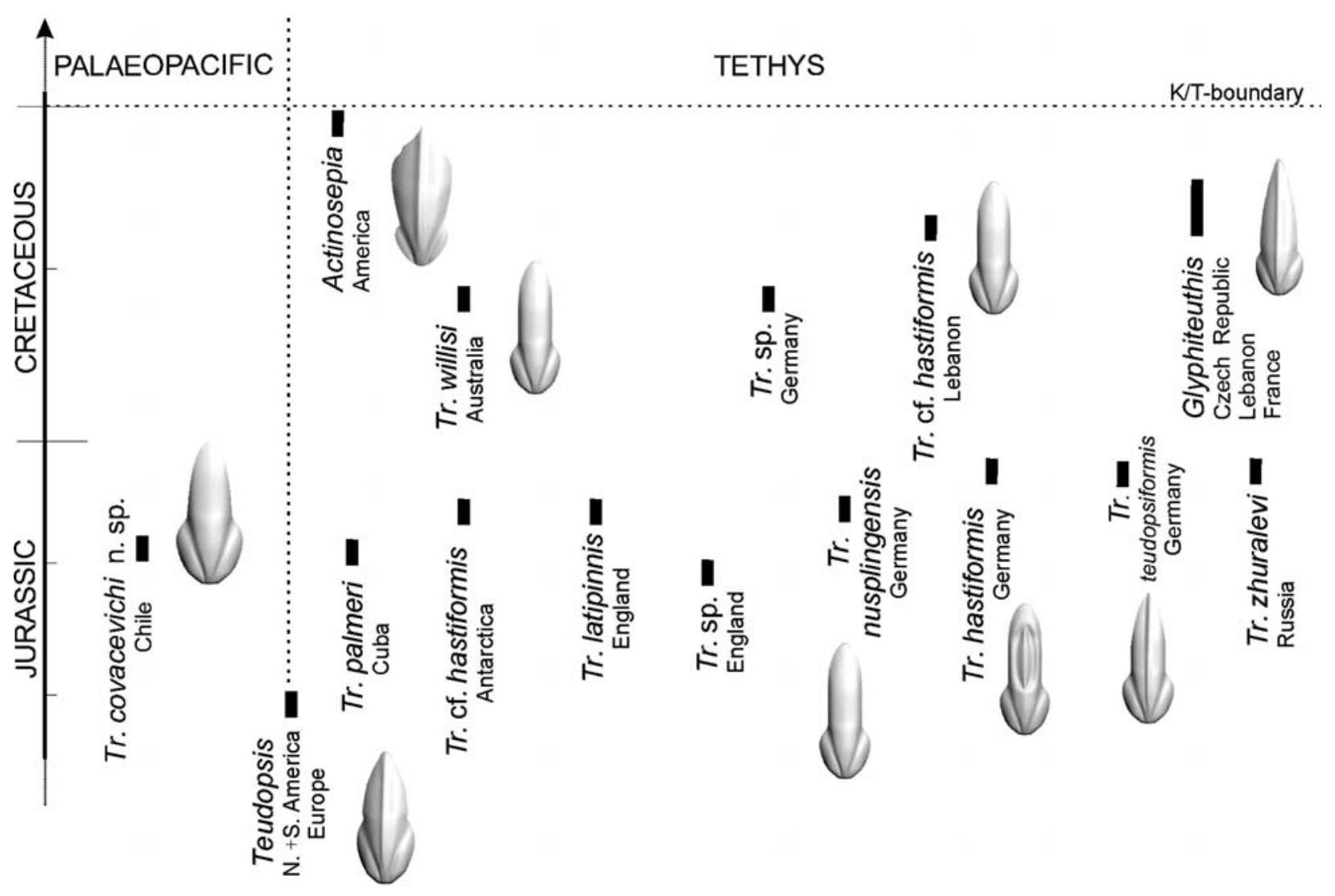

Figure 7. Stratigraphic and geographic records of trachyteuthids and some teudopsids. 
habitat for Tr. covacevichi n. sp. The same palaeoenvironment is also assumed for other trachyteuthids from the tethyal realm.

\section{Acknowledgments}

The authors thank Gloria Arratia, Kate Shaw, John Chorn, all from Lawrence, Kansas, at that time, and the late Vladimir Covacevich, Servicio Nacional de Geología y Minería, Santiago, Chile, for their valuable help during the field work in the Cordillera de Domeyko, and César Cáceres, Director Regional, Servicio Nacional de Geología y Minería, Antofagasta, for support with field equipment. The field work was supported by National Geographic Society grant 5118-93 to G. Arratia and H.-P. Schultze. We are also grateful to Ernesto Pérez d'A. from Santiago, Chile, who kindly provided useful photographs of additional specimens from the same field trip. For proof-reading and critical comments on the manuscript we are greatly indebted to Helmut Keupp (Berlin) and Kazushige Tanabe (Tokyo).

\section{References}

Arratia, G. 1987. Jurassic fishes from Chile and critical comments. In Volkheimer, W. (ed.). Bioestratigrafía de los Sistemas Regionales del Jurásico y Cretácico en América del Sur. Vol. 1. Comité Sudamericano del Jurásico y Cretácico, Mendoza, Argentina: pp. 257-286.

Arratia, G. 1994. Phylogenetic and Palaeogeographic relationships of the varasichthyid group (Teleostei) from the Late Jurassic of Chile. - Revista Geologica de Chile 21: 119-165.

Arratia, G. \& Cione, A. 1996. The Record of Fossil Fishes of Southern South America. In Arratia, G. (ed.). Contributions of Southern South America to Vertebrate Palaeontology. - Münchner Geowissenschaftliche Abhandlungen, Reihe A: Geologie und Paläontologie 30: 9-72.

Arratia, G. \& Schultze, H.-P. 1999. Mesozoic fishes from Chile. In Arratia, G. \& Schultze, H.-P. (eds). Mesozoic Fishes 2. Systematics and Fossil Record: Verlag Dr. Friedrich Pfeil, München: pp. 565-593.

Bandel, K. \& Leich, H. 1986. Jurassic Vampyromorpha (dibranchiate cephalopods). - Neues Jahrbuch für Geologie und Paläontologie, Monatshefte 1986 (3): 129-148.

Bather, F. A. 1888. Shell-growth in Cephalopoda (Siphonopoda). Annals and Magazine of Natural History 6 (1): 421-427.

Bizikov, V. A. 2004. The shell in Vampyropoda (Cephalopoda): morphology, functional role and evolution. - Ruthenica, Supplement 3: 1-88.

Boletzky, S. v. 1992. Evolutionary aspects of development, life style, and reproduction mode in incirrate octopods (Mollusca, Cephalopoda). - Revue suisse de zoologie 4: 755-770.

Chong, G. \& Förster, R. 1976. Chilenophoberus atacamensis, a new decapod crustacean from the Middle Oxfordian of the Cordillera de Domeyko, northern Chile. - Neues Jahrbuch für Geologie und Paläontologie, Monatshefte 1976: 145-156.

Crick, G. C. 1896. On a specimen of Coccoteuthis hastiformis, Rüppell, sp., from the Lithographic Stone, Solenhofen, Bavaria. Geological Magazine 3, 3: 439-443.

Doguzhaeva, L. A. 1996. Two Early Cretaceous spirulid coleoids of the northwestern Caucasus: Their shell ultrastructure and evolutionary implications. - Palaeontology 39 (3): 681-707.

Doguzhaeva, L. A. 2000. A rare coleoid mollusc from the Upper Jurassic of central Russia. - Acta Palaeontologica Polonica 45: 389-406.

Doguzhaeva, L. A., Mapes, R. H. \& Mutvei, H. 1999. A Late Carboniferous spirulid Coleoid from the southern mid-continent (USA). In Oloriz, F. \& Rodriguez-Tovar, F. J. (eds). Advancing research on living and fossil cephalopds. Kluwer Academic/Plenum, New York: $47-57$
Doguzhaeva, L. A. \& Mutvei, H. 2003. Gladius composition and ultrastructure in extinct squid-like coleoids Loligosepia, Trachyteuthis and Teudopsis. - Revue de Paléobiologie 22 (2): 877894.

Donovan, D. T. 1977. Evolution of the dibranchiate Cephalopoda. Symposia of the Zoological Society of London 38: 15-48.

Donovan, D. T. 1995. A specimen of Trachyteuthis (Coleoidea) with fins from the Upper Jurassic of Solnhofen (Bavaria). - Stuttgarter Beiträge zur Naturkunde, Serie B 235: 1-8

Donovan, D. T., Doguzhaeva, L. A. \& Mutvei, H. 2003. Two pairs of fins in the Late Jurassic Coleoid Trachyteuthis from southern Germany. - Berliner Paläobiologische Abhandlungen 3: 91-99.

Doyle, P. 1991. Teuthid Cephalopods from the Upper Jurassic of Antartica. - Palaeontology 34: 169-178.

Doyle, P., Donovan, D. T. \& Nixon, M. 1994. Phylogeny and systematics of the Coleoida. - Paleontological contributions, University of Kansas, New Series 5: 1-15.

Engeser, T. 1988. Vampyromorpha ("Fossile Teuthiden"). In Westphal, F. (ed.). Fossilium Catalogus. I: Animalia. Kugler Publications, Amsterdam.

Fioroni, P. 1982. Zur Epidermis- und Saugnapfentwicklung bei Octopoden, ein entwicklungsgeschichtlicher Vergleich. - Revue suisse de zoologie 89: $355-374$

Fuchs, D. 2006a. Fossil erhaltungsfähige Merkmalskomplexe der Coleoidea (Cephalopoda) und ihre phylogenetische Bedeutung. Berliner Paläobiologische Abhandlungen 8: 1-115.

Fuchs, D. 2006b. Diversity, Taxonomy and Morphology of vampyropod Coleoids (Cephalopoda) from the Upper Cretaceous of Lebanon. - Memorie Società Italiana di Scienze Naturali, Museo di Storia Naturale Milano 34 (2): 1-28.

Fuchs, D. 2006c. Re-description of Doryanthes munsterii (d'Orbigny, 1845), a poorly known coleoid cephalopod from the Late Jurassic Solnhofen Plattenkalks. - Archaeopteryx 24: 79-88.

Fuchs, D., Keupp, H. \& Engeser, T. 2003. New records of soft parts of Muensterella scutellaris Münster, 1842 (Coleoidea) from the Late Jurassic Plattenkalks of Eichstätt and their significance for octobrachian relationships. - Berliner Paläobiologische Abhandlungen 3: 101-111.

Fuchs, D., Engeser, T. \& Keupp, H. (2007). Gladius shape variation in the genus Trachyteuthis Meyer 1846 (Cephalopoda: Coleoidea) from the Late Jurassic Plattenkalks of Nusplingen (Kimmeridgian) and Solnhofen (Tithonian). - Acta Palaeontologica Polonica 52 (3): 575-589

Haas, W. 2002. The evolutionary history of the eight-armed Coleoidea. In Summesberger, H., Histon, K. \& Daurer, A. (eds). Cephalopods - Present and Past. - Abhandlungen der Geologischen Bundesanstalt 57: 305-326.

Hall, R. L. 1985. Paraplesioteuthis hastata (Münster), the first teuthid squid recorded from the Jurassic of North America. - Journal of Paleontology 59: 870-874.

Hall, R. L. \& Neuman, A. G. 1989. Teudopsis cadominensis, a new teuthid squid from the Toarcian (Lower Jurassic) of Alberta. Journal of Paleontology 63: 324-327.

Hecker, E. L. \& Hecker, R. F. 1955. [Teuthidenreste aus dem Oberen Jura und der Unteren Kreide des Mittleren Wolga-Gebietes.] Vorpommerische Paläontologie 2: 36-44.

Hewitt, R. A. \& Wignall, P. B. 1988. Structure and phylogenetic significance of Trachyteuthis (Coleoidea) from the Kimmeridge Clay of England. - Proceedings of the Yorkshire Geological Society 47 (2): $149-153$

Jeletzky, J. A. 1966. Comparative morphology, phylogeny and classification of fossil Coleoidea. - Paleontological contributions, University of Kansas, Mollusca 7: 1-16.

Klug, C., Schweigert, G., Dietl, G. \& Fuchs, D. 2005. Coleoid beaks from the Nusplingen Lithographic Limestone (Late Kimmeridgian, SW Germany). - Lethaia 38: 173-192. 
Kretzoi, M. 1942. Necroteuthis n. gen. (Ceph. Dibr. Necroteuthidae n. f.) aus dem Oligozän von Budapest und das System der Dibranchiata. - Földtani Közlöny 72: 124-138.

Kriwet, J. 2000. Revision of Mesturus cordillera Martill et al., 1998 (Actinopterygii, Pycnodontiformes) from the Oxfordian (Upper Jurassic) of northern Chile. - Journal of Vertebrate Paleontology 20 (3): 450-455.

Martill, D. M. \& Hudson, J. D. 1994. Fossilien aus Ornatenton und Oxford Clay. Quelle \& Meyer, Wiebelsheim.

Meyer, H. v. 1846. Mitteilungen an Prof. Bronn gerichtet. - Neues Jahrbuch für Mineralogie, Geognosie, Geologie und Petrefactenkunde 1846: 596-599.

Naef, A. 1921. Das System der dibranchiaten Cephalopoden und die mediteranen Arten derselben. - Mitteilungen aus der zoologischen Station zu Neapel 22: 527-542.

Naef, A. 1922. Die fossilen Tintenfische - Eine paläozoologische Monographie. Gustav Fischer Verlag, Jena.

Owen, R. 1855. Notice of a new species of an extinct genus of dibranchiate Cephalopod (Coccoteuthis latipinnis) from the upper Oolithic Shales at Kimmeridge. - Quarterly Journal of the Geological Society of London 11: 124.

Regteren Altena, C. O. van 1949. Teyler's Museum systematic catalogue of the palaeontological collection - sixth supplement (Teuthoidea). - Archives de Musée Teyler, Series 3, 10: 53-62.

Reuss, A. E. 1854. Loliginidenreste in der Kreideformation. - Abhandlungen der königlichen böhmischen Gesellschaft für Wissenschaften 5 (8): 29-32.

Riccardi, A. C. 2005. First teuthid cephalopod from the Lower Jurassic of South America (Neuquen Basin, Argentina). - Geologica Acta 3 (2): 179-184.

Riegraf, W., Janssen, N. \& Schmitt-Riegraf, C. 1998. Cephalopoda dibranchiata fossiles (Coleoidea) II/Supplementum ad mandibula fossiles ammonitorum et nautilorum (Rhyncholithi et Rhyncho- teuthes, excl. aptychi et anaptychi). In Westphal, F. (ed.). Fossilium Catalogus. I: Animalia 135. Kugler Publications, Amsterdam.

Robson, G. C. 1929. On the rare abyssal octopod Melanoteuthis beebei (sp. n.): a contribution to the phylogeny of the Otopoda. Proceedings of the Zoological Society of London, 1929: 469-486.

Roger, J. 1952. Sous-class des Dibranchiata OWEN 1836. In Piveteau, J. (ed.). Traité de Paléontologie. Tome II. Problèmes d'adaptation et phylogénèse. Masson \& Cie., Paris: 689-755.

Rubilar, A. R. \& Pérez dA., E. 2006. Nuevos restos fosiles de teuthidos (Cephalopoda, Coleoidea) en Chile. - XI Congreso Geologico Chileno, Actas 2: 113-116.

Rüppell, E. 1829. Abbildung und Beschreibung einiger neuer oder wenig bekannter Versteinerungen aus der Kalkschieferformation von Solnhofen. Brönner Verlag, Frankfurt/M.

Schevill, W. E. 1950. An Upper Jurassic sepioid from Cuba. - Journal of Paleontology 24 (1): 99-101.

Schultze, H.-P. 1989. Three-dimensional muscle preservation in Jurassic fishes of Chile. - Revista Geologica de Chile 16 (2): 183215.

Smith, A. G., Smith, D. G. \& Funnell, B. M. 1994. Atlas of Mesozoic and Cenozoic Coastlines. IX +99 pp., Cambridge University Press, Cambridge, New York, Melbourne.

Starobogatov, Y. I. 1983. [The System of the Cephalopoda.] In Starobogatov, Y. I. \& Nesis, K. N. (eds). [Taxonomy and ecology of Cephalopoda] Zoological Institute, USSR Academy of Sciences, Leningrad [in Russian]: pp. 4-7.

Wade, M. 1993. New Kelaenida and Vampyromorpha: Cretaceous squid from Queensland. - Memoirs of the Association of Australasian Palaeontologists 15: 353-374.

Whiteaves, J. F. 1897. Some remains of a sepia-like cuttlefish from the Cretaceous rocks of the South Saskatchewan. - The Canadian Record of Science 7: 459-462. 